\title{
Design, Synthesis and Docking Studies of a Novel Ciprofloxacin Analogue as an Antimicrobial AGENT
}

\author{
S.JUBIE* ${ }^{*}$ R. KALIRAJAN and PAVANKUMAR YADAV, \\ Department of Pharmaceutical Chemistry \\ J.S.S. College of Pharmacy, off campus - JSS University, Mysore \\ jubiejawahar@gmail.com
}

Received 31 July 2011; Accepted 4 October 2011

\begin{abstract}
The carboxylic acid group of ciprofloxacin was modified and amino mercapto triazole was substituted. The compound was confirmed by physical parameters (solubility, melting point), chromatographic methods (TLC) and consistent with its IR \& ${ }^{1}$ HNMR spectra. The synthesized analogue was screened for antibacterial activity against one gram positive \& two gram negative species. The compound exhibited good antibacterial effect towards gram negative species when compared to the standard ciprofloxacin. At the same time the analogue was retaining antibacterial activity towards gram positive species when compared to standard ciprofloxacin. The molecular docking studies showed a good correlation between their antibacterial activity and autodock binding free energy.
\end{abstract}

Keywords: Ciprofloxacin, 1,2,4-Triazole, Molecular docking, Antimicrobial

\section{Introduction}

Quinolones have become a major class of antibacterial agents, which are under extensive clinical development. They have an attraction because of their extremely potent activity, rapid bactericidal effects and low incidence of resistance development ${ }^{1}$. The main disadvantage of the quinolones is their limited activity against gram positive pathogens and methicillin-resistant Staphylococcus aureus (MRSA) ${ }^{2}$. In addition, quinolones can cause certain adverse effects, such as CNS effects, phototoxicity, tendonitis, hypoglycemia, and serious cardiac dysrhythmias ${ }^{3-4}$. Thus, despite many advances in the fluoroquinolone field, there exists continuous need for novel quinolones with better activity profile, pharmacokinetics and tolerability, to overcome the limitations of existing drugs. Ciprofloxacin is a second generation fluoroquinolone used to treat various bacterial infections. It is more effective against gram- negative organisms than gram- positive ones. This moderate activity against some of the gram positive species limited its use in bacterial infections.

Molecular docking plays an important role in the rational design of drugs. In the field of molecular modeling, docking is a method which predicts the preferred orientation of one molecule to a second when bound to each other to form a stable complex. Molecular docking 
can be defined as an optimization problem, which would describe the "best-fit" orientation of a ligand that binds to a particular protein of interest ${ }^{6} .1,2,4$-Triazole was reported to have a broad spectrum of antibacterial activity ${ }^{7-8}$. Therefore on continuation of our work ${ }^{9-11}$, in this study we introduced 1, 2, 4-triazole into the quinolone antibacterial ciprofloxacin at its C-3 position and screen their antibacterial activity. Molecular docking studies was then employed for the analysis with training set composed synthesized compound whose inhibitory activity is unknown, in order to find out the molecular facilities responsible for biological activities.

\section{Experimental}

Melting points were taken in glass capillary tubes on a Veego VMP-1 Apparatus and are uncorrected. The synthetic work was done by using CATALYST Scientific microwave synthesis system. The ${ }^{1} \mathrm{H}-\mathrm{NMR}$ were recorded on Bruker DRX-300 (300 MHz FT-NMR) using DMSO as solvent and TMS as internal standard. The IR spectra of compounds were recorded on Shimadzu FT-IR spectrometer using $\mathrm{KBr}$ pellet technique and are expressed in $\mathrm{cm}^{-1}$. ${ }^{1} \mathrm{HNMR}$ spectra were recorded on a DPX-300 MHz Bruker FTNMR spectrometer (Bruker, USA). Chemical shifts were reported as parts per million ( $\partial \mathrm{ppm})$ with tetramethyl silane (TMS) as an internal standard.

\section{Synthesis of thiocarbohydrazide (1)}

Hydrazine hydrate $(0.3 \mathrm{~mol}, 9 \mathrm{~mL})$ and 2-chloro ethanol $(0.015 \mathrm{~mol}, 0.5 \mathrm{~mL})$ were added to three neck flask. Carbon disulphide $(0.1 \mathrm{~mol}, 3 \mathrm{~mL})$ was added drop wise with stirring in ice bath, a yellow solid is formed. Finally sodium hydroxide $(0.015 \mathrm{~mol}, 0.3 \mathrm{~g})$ was added and subjected to microwave irradiation at $400 \mathrm{~W}$ for 15 minutes. The reaction mixture was cooled and the solid obtained by filtration was washed by methanol and re crystallized from boiling water ${ }^{12}$.

TLC: Chloroform: Methanol (9:1) IR $\left(\mathrm{KBr} \mathrm{cm}^{-1}\right)$ : $3022.55\left(\mathrm{NH}_{2} \mathrm{str}\right), 2918.40$ (Ar C-H str), 3211.59 (NH str), 1143.8 (C-N str), 680.89 (C=S str), 977.94(N-C-S str).

\section{Synthesis of triazole substituted ciprofloxacin (2)}

Ciprofloxacin $(0.3314 \mathrm{~g}, 0.001 \mathrm{~mol})$ and thiocarbohydrazide $(0.212 \mathrm{~g}, 0.002 \mathrm{~mol})$ are taken in a round bottom flask. The reaction mixture was kept under reflux in a water bath for $12 \mathrm{~h}$. Then the reaction mixture was cooled. The product formed was filtered, dried and crystallized from ethanol.

TLC: Chloroform: Methanol (9:1) IR $\left(\mathrm{KBr} \mathrm{cm}^{-1}\right)$ : 3265.59(NH str heterocyclic), 1257.63(C-N str), 1192.05(SH str) 1720.56 (C=O str), 1012.10(C- Fstr), 1238.34(N-N-Cstr), 902.72(C=Sstr). NMR (ppm) : $8.6(\mathrm{~s}, 1 \mathrm{H}, \mathrm{N}-\mathrm{CH}), 2.0\left(\mathrm{~S}, 2 \mathrm{H}, \mathrm{NH}_{2}\right), 7.5(\mathrm{~m}, 3 \mathrm{H}, \mathrm{Ar}-\mathrm{H}), 3.0$ (s, $1 \mathrm{H}, \mathrm{SH}), 3.2$ (m, 8H, piperazine), 1.2 (d, 5H, cyclopropyl).

\section{Molecular docking studies}

\section{Protein structure retrieval}

The PDB is a key isomer in areas of structural biology, is a key repository for 3D structure data of large molecule. The protein was extracted from protein database at the NCBI.

\section{Lead preparation and energy minimization}

The synthesized compounds which are derivatives of Ofloxacin were taken for prediction of 3D structures by using Cambridge software. The energy was minimized for flexible docking using Argus lab. The structures of these synthesized compounds and enzyme are shown in Figure 1. 
982 S. JUBIE et al.
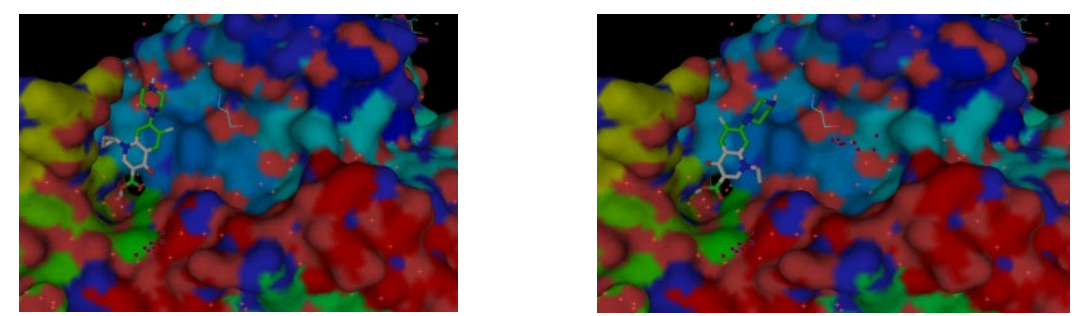

$\mathrm{CF}_{\mathrm{a}}$
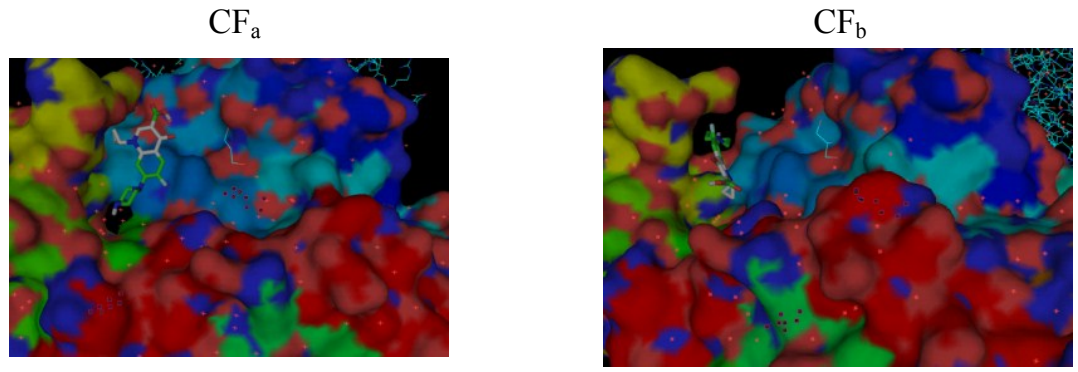

$\mathrm{CF}_{\mathrm{c}}$

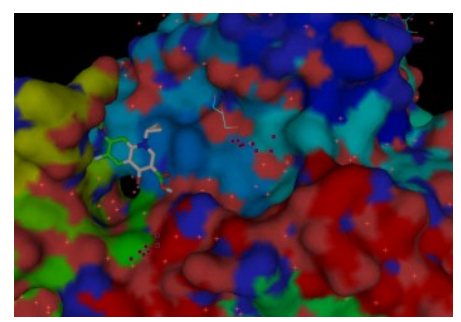

$\mathrm{CF}_{\mathrm{e}}$

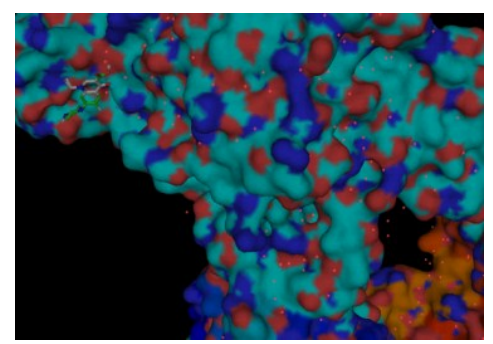

$\mathrm{CF}_{\mathrm{g}}$

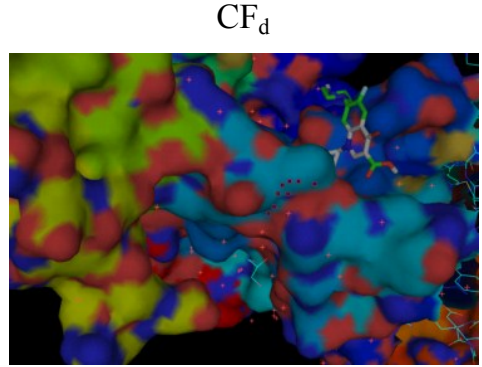

$\mathrm{CF}_{\mathrm{f}}$

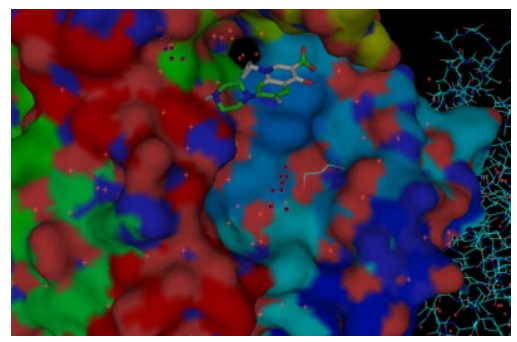

$\mathrm{CF}_{\mathrm{h}}$

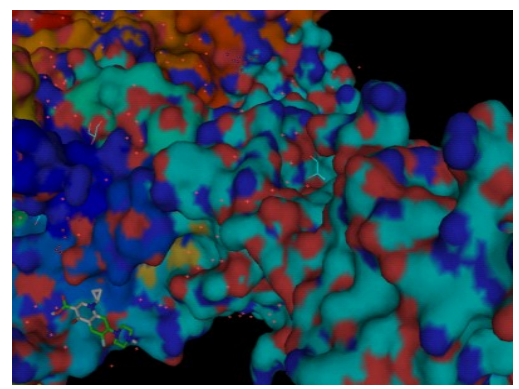

$\mathrm{CF}_{\mathrm{i}}$

Figure 1. Different modes of ciprofloxacin. 


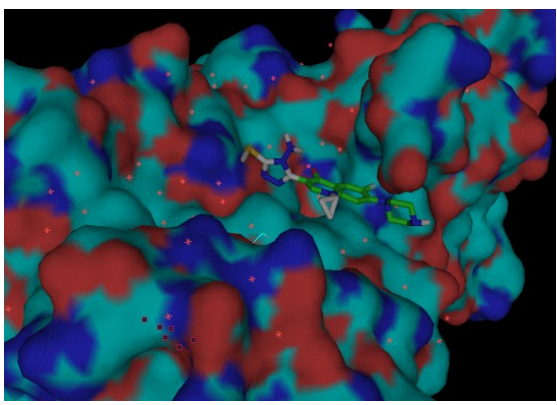

$2_{\mathrm{a}}$

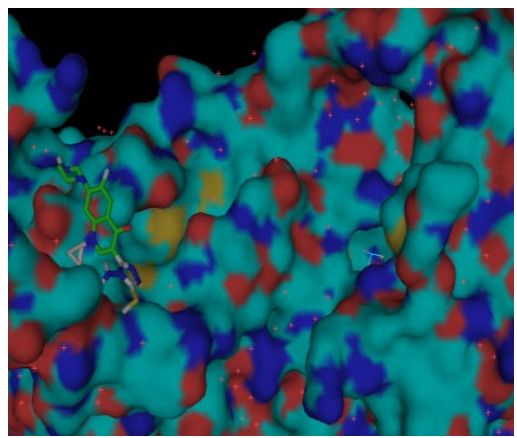

$2_{\mathrm{c}}$

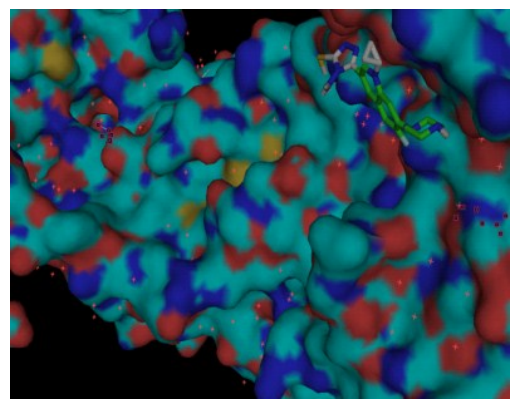

2 e

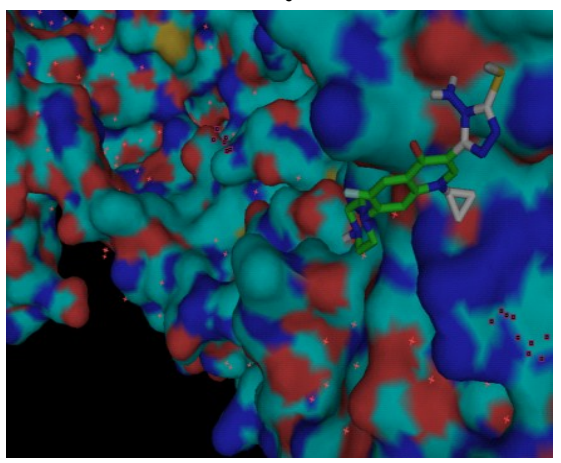

$2_{\mathrm{g}}$

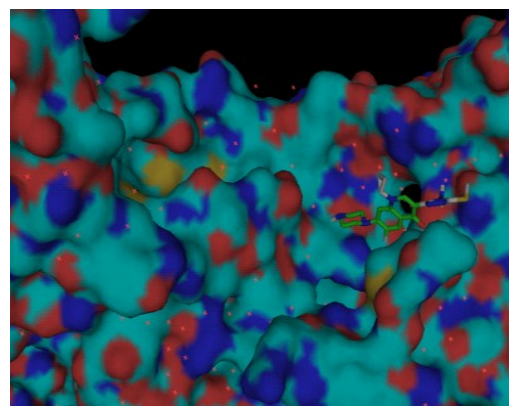

$2 \mathrm{~b}$

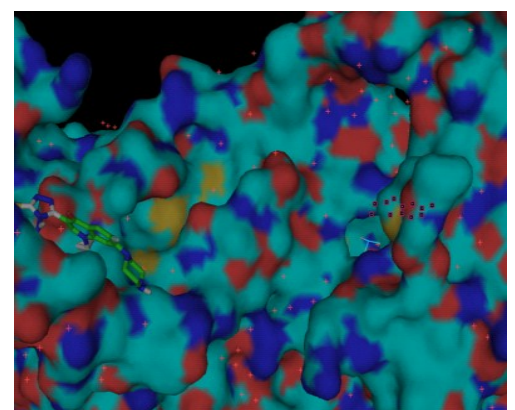

$2_{\mathrm{d}}$

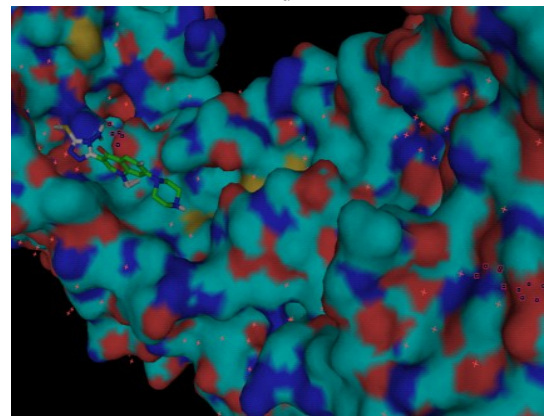

$2_{\mathrm{f}}$

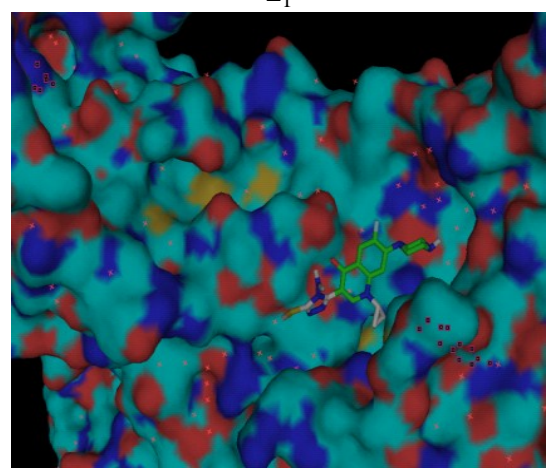

$2 \mathrm{~h}$

Figure 2. Continued. 


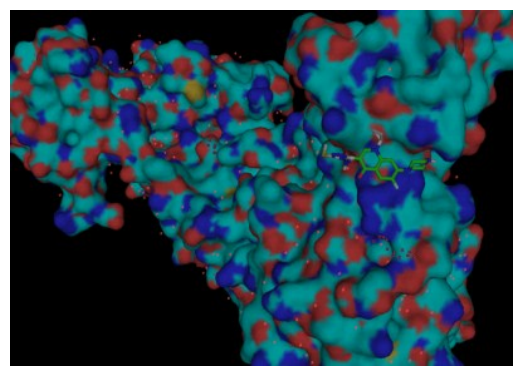

$2_{\mathrm{i}}$

Figure 2. Different modes of synthesized compounds.

Receptor grid generation (auto dock vina 4.0)

In the receptor Grid Generation the receptor structure was defined by excluding any cocrystallized ligand that may be present, determine the position and size of the active site as it will be represented by receptor grids.

\section{Molecular docking}

During the docking process, initially Auto dock Vina performs a complete systematic search of the conformational, oriental and positional space of the docked ligand and eliminating unwanted conformations using scoring and followed by energy optimization. Predicting the binding affinity and rank-ordering ligands in database screens was implemented by modified and expanded version of the Chemscore 18 scoring function, for use in. For our studies, x-ray crystal structure of synthesized compounds was taken from PDB, having resolution of $0.375 \mathrm{~A}^{0}$. Solvent molecules were deleted and bond order for crystal ligand and protein were adjusted and minimized. Using standard precision (SP) mode of PyMOL software, docking studies was performed on synthesized compounds ${ }^{13}$.

\section{Antimicrobial evaluation}

All the synthesized compounds were screened for their antibacterial activity against B.subtilis, K.pneumoniae \& P.aeruginosa by using disc diffusion method ${ }^{14}$. Bacteria were cultured in nutrient agar medium and used as inoculum for study. The test compounds were dissolved in N, Ndimethyl formamide (DMF) to obtain a solution of 25,50 and $100 \mu \mathrm{g} / \mathrm{mL}$ concentration. The data are given in Table 1. The compounds were also screened for their in-vitro antifungal activities against A. Niger, C.albicans \& R.nigricans. The inhibitory activities were compared with the commercial fungicide griseofulvin. The compounds exhibited varying degree of activity. The data are given in Table 2.

Table 1. Different docking modes of ciprofloxacin\&triazole substituted ciprofloxacin.

\begin{tabular}{cccccccccc}
\hline \multirow{2}{*}{ Com } & \multicolumn{3}{c}{ B.subtilis } & \multicolumn{3}{c}{ K.pneumoniae } & \multicolumn{3}{c}{ P.aeruginosa } \\
& \multicolumn{3}{c}{ Conc, $\mu \mathrm{g} / \mathrm{mL}$} & \multicolumn{3}{c}{ Conc, $\mu \mathrm{g} / \mathrm{mL}$} & \multicolumn{3}{c}{ Conc, $\mu \mathrm{g} / \mathrm{mL}$} \\
\hline \multirow{3}{*}{ Con } & 25, & 50, & 100, & 25, & 50, & 100, & 25, & 50, & 100, \\
& $\mu \mathrm{g} / \mathrm{mL}$ & $\mu \mathrm{g} / \mathrm{mL}$ & $\mu \mathrm{g} / \mathrm{mL}$ & $\mu \mathrm{g} / \mathrm{mL}$ & $\mu \mathrm{g} / \mathrm{mL}$ & $\mu \mathrm{g} / \mathrm{mL}$ & $\mu \mathrm{g} / \mathrm{mL}$ & $\mu \mathrm{g} / \mathrm{mL}$ & $\mu \mathrm{g} / \mathrm{mL}$ \\
& $\pm \mathrm{S} . \mathrm{E}$ & $\pm \mathrm{S} . \mathrm{E}$ & $\pm \mathrm{S} . \mathrm{E}$ & $\pm \mathrm{S} . \mathrm{E}$ & $\pm \mathrm{S} . \mathrm{E}$ & $\pm \mathrm{S} . \mathrm{E}$ & $\pm \mathrm{S} . \mathrm{E}$ & $\pm \mathrm{S} . \mathrm{E}$ & $\pm \mathrm{S} . \mathrm{E}$ \\
\multirow{3}{*}{1} & 12.3 & 13.6 & 17.3 & 11 & $14.6 \pm 0.33$ & 17.6 & 11.6 & 13.3 & 15.3 \\
& \pm 0.33 & \pm 0.33 & \pm 0.33 & \pm 0.00 & & \pm 0.33 & \pm 0.33 & \pm 0.33 & \pm 0.33 \\
\multirow{2}{*}{2} & 37.6 & 39.3 & 41 & 35.6 & $38.6 \pm 0.33$ & 45.6 & 30 & 40.3 & 44.6 \\
& \pm 0.33 & \pm 0.33 & \pm 0.57 & \pm 0.33 & & \pm 0.33 & \pm 0.57 & \pm 0.33 & \pm 0.33 \\
$\mathrm{CF}$ & 32.3 & 37.6 & 42 & 33.6 & $35.3 \pm 0.33$ & 40 & 33.6 & 39.3 & 43 \\
& \pm 0.33 & \pm 0.33 & \pm 0.57 & \pm 0.33 & & \pm 0.57 & \pm 0.33 & \pm 0.33 & \pm 0.57 \\
\hline
\end{tabular}

3ILW-Topoisomerase II 2- Triazole substituted ciprofloxacin. 
Table 2. Antibacterial activity of synthesized compounds.

\begin{tabular}{ccccc}
\hline \multirow{2}{*}{ Docking } & \multirow{2}{*}{ Mode } & $\begin{array}{c}\text { Affinity } \\
\text { (kcal/mol) }\end{array}$ & \multicolumn{2}{c}{ Dist from bestmode } \\
\cline { 3 - 5 } & 1 & -6.7 & 0.000 & Rmsd u.b \\
\hline \multirow{3}{*}{ 3ILW Vs Cipro } & 2 & -6.7 & 2.867 & 5.000 \\
& 3 & -6.4 & 2.236 & 3.799 \\
& 4 & -6.1 & 3.942 & 4.862 \\
& 5 & -6.0 & 3.537 & 6.614 \\
& 6 & -5.8 & 18.477 & 20.581 \\
& 7 & -5.6 & 4.493 & 7.177 \\
& 8 & -5.6 & 58.110 & 60.053 \\
& 9 & -5.6 & 15.824 & 17.496 \\
& 1 & -6.2 & 0.000 & 0.000 \\
& 2 & -6.0 & 46.149 & 49.365 \\
& 3 & -5.8 & 18.770 & 20.961 \\
& 4 & -5.7 & 15.789 & 17.451 \\
& 5 & -5.6 & 53.120 & 56.581 \\
& 6 & -5.5 & 16.983 & 18.814 \\
& 7 & -5.4 & 67.274 & 71.018 \\
& 8 & -5.4 & 40.663 & 43.135 \\
& 9 & -5.4 & 68.010 & 71.680 \\
\hline
\end{tabular}

\section{Results and Discussion}

The starting material thiocarbohydrazide was prepared according to the literature method by reacting hydrazine hydrate and carbon disulphide. This was directly fused with the carboxylic group of ciprofloxacin to get the triazole. The synthesized final compound was first purified by successive recrystallization using appropriate solvents. The purity of the synthesized compound was checked by performing thin layer chromatography and determining melting points. IR and ${ }^{1} \mathrm{HNMR}$ spectra were consistent with the assigned structure.

Molecular docking studies was employed for the analysis with training set composed of our synthesized compound whose inhibitory activity is unknown, in order to find out the molecular facilities responsible for biological activities. Ciprofloxacin and derivative of ciprofloxacin (2) were taken for docking study. The compound used for docking showed best fit (Root Mean Square Difference (rmsd) value of 0.000) with topoisomerase (3ILW) protein. In order to determine the ability of autodock 4.0, to reproduce the orientation and position of compounds in 3ILW protein, the standard and the derivative of ciprofloxacin were extracted and docked back into the corresponding binding pocket. The compound tested for docking study showed high affinity with low energy of $-6.2 \mathrm{kcal} / \mathrm{mol}$ with employed protein. Binding between 3ILW \& compound indicates very good inhibition with rmsd value of 0.000 .Ciprofloxacin showed high affinity with low energy of $-6.7 \mathrm{kcal} / \mathrm{mol}$ with employed protein. Since our titled compounds are known to possess antimicrobial activity, the compounds were screened for their antibacterial and antifungal activity by cupplate method. They were screened for antimicrobial activity against three bacterial strains (two gram negative Klebsiella pneumoniae and Pseudomonas aeruginosa and one gram positive Bacillus subtilis) and three fungal strains (Aspergillus niger, Rhizopus nigricans, Candida albicans) by cup plate method (Table 3). Ethanol was used as control, showed no zone of inhibition. The compounds were active against all the bacterial strains included in testing. 
Table 3. Antifungal activity of the synthesized compounds.

\begin{tabular}{cccc}
\hline Com & \multicolumn{3}{c}{ C.albicans Conc, $\mu \mathrm{g} / \mathrm{mL}$} \\
\hline Con & $25, \mu \mathrm{g} / \mathrm{mL} \pm$ S.E & $50, \mu \mathrm{g} / \mathrm{mL} \pm$ S.E & $100, \mu \mathrm{g} / \mathrm{mL} \pm$ S.E \\
1 & - & - & $48 \pm 0.00$ \\
2 & - & - & $70 \pm 0.00$ \\
$\mathrm{CF}$ & - & - & $36.6 \pm 0$. \\
\hline
\end{tabular}

The triazole substituted ciprofloxacin showed good antibacterial activity against gram negative bacteria but it was found to have moderate activity against gram positive bacteria when compared to the standard.The titled compounds were tested for their antifungal activity with three fungal strains (Aspergillus niger, Rhizopus nigricans, Candida albicans) by using cup plate method (Table 6). All the fungal strains tested for assay showed susceptible to all tested compounds, except Candida albicans. The triazole substituted ciprofloxacin showed good antifungal activity against Candida albicans with zone of inhibition of $70 \pm 0.00 \mathrm{~mm}$.

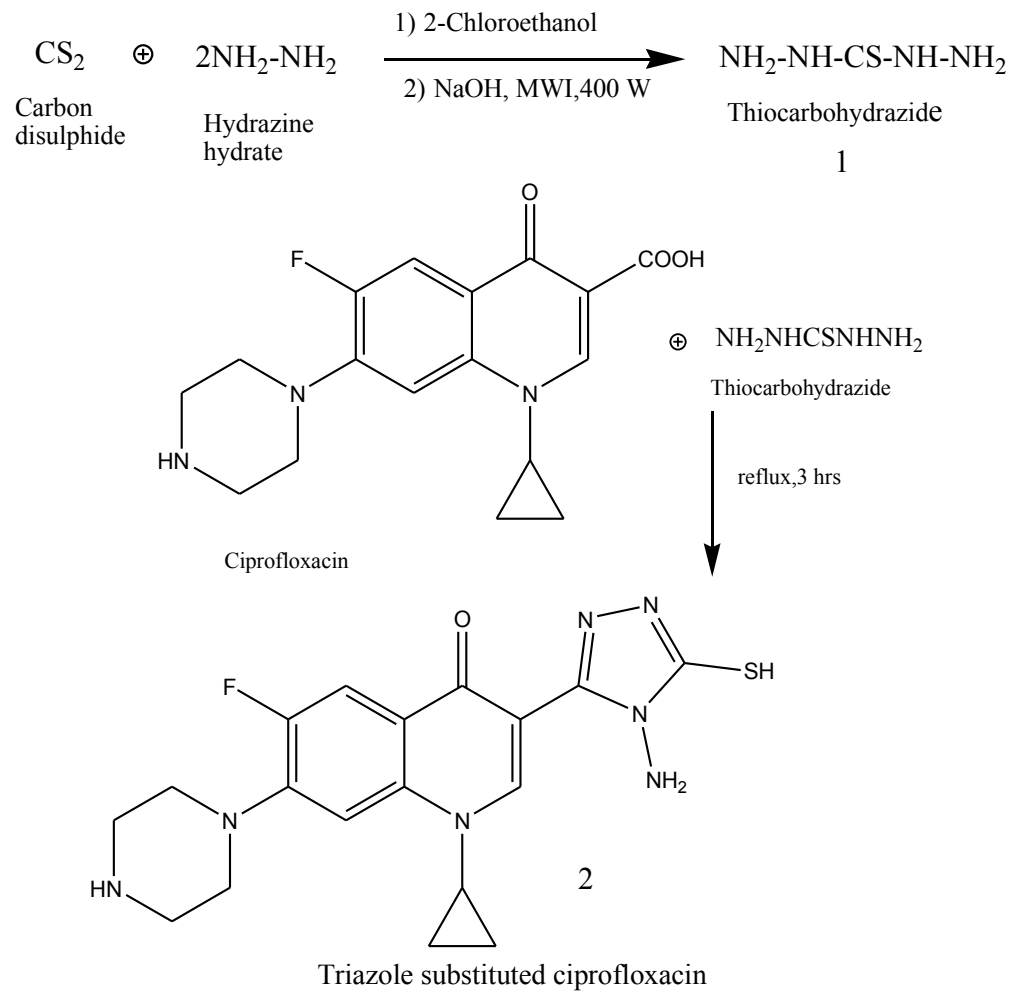

Scheme

\section{References}

1. Hooper D C and Wifson J C, Antimicrob Agents Chemother, 1985, 28, 716.

2. Ball P, Infection, 1994, 22, 140.

3. Ball P L, Mandell Y N and Tilloston G, Drug Safety, 1999, 21, 407.

4. Ball P J, Antimicrob Agents Chemother., 2000, 45, 557. 
5. Kawahara S and Nippon R, Chemother., 1998, 56 (12), 3096-3099.

6. Lengauer T and Rarey M, Curr Opin Struct Biol., 1996, 6(3), 402-406.

7. Nagalakshmi G D, Univ J Pharm Sci., 2006, 6(2), 69-75.

8. Wu J, Liu X, Cheng X, Cao Y, Wang D and Li Z, Molecules, 2007, 12, 2003-2016.

9. Jubie S, Prabitha P, Rajesh Kumar R, Kalirajan R, Gayathri R, Sankar S and Elango K, Med Chem Res., DOI 10.1007/s00044-011-96588.

10. Jubie S, Pranabesh S, Kalirajan R, Gowramma B, Gomathy S, Sankar S and Elango K, $J$ Pharm Res., 2010, 3(3), 511-513.

11. Jubie S, Rajeshkumar R, Yellareddy B, Siddhartha G, Sandeep M, Surendrareddy K, Dushyanth H.S and Elango K, J Pharm Sci Res., 2010, 2(2), 69-76.

12. Lengauer T and Rarey M, Curr Opin Struct Biol., 1996, 6(3), 402-406.

13. Jorgensen W L, Science, 1991,254, 954-955.

14. Foroumadi A, Godsi S, Emami S, Samadi N and Ali G, Bioorg Med Chem Lett., 2006, 16, 3499-3503. 


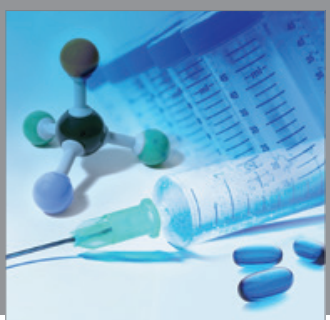

International Journal of

Medicinal Chemistry

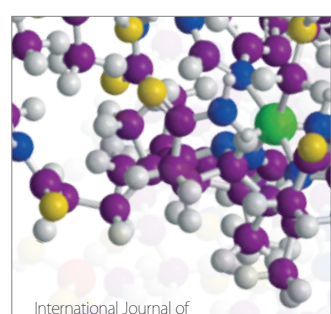

Carbohydrate Chemistry

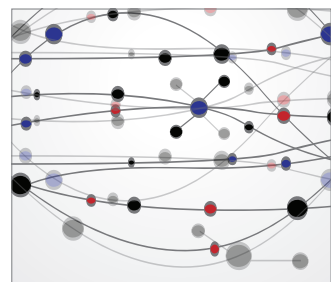

The Scientific World Journal
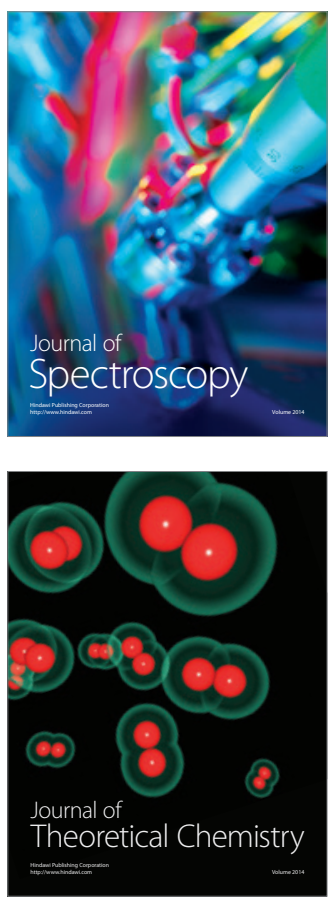
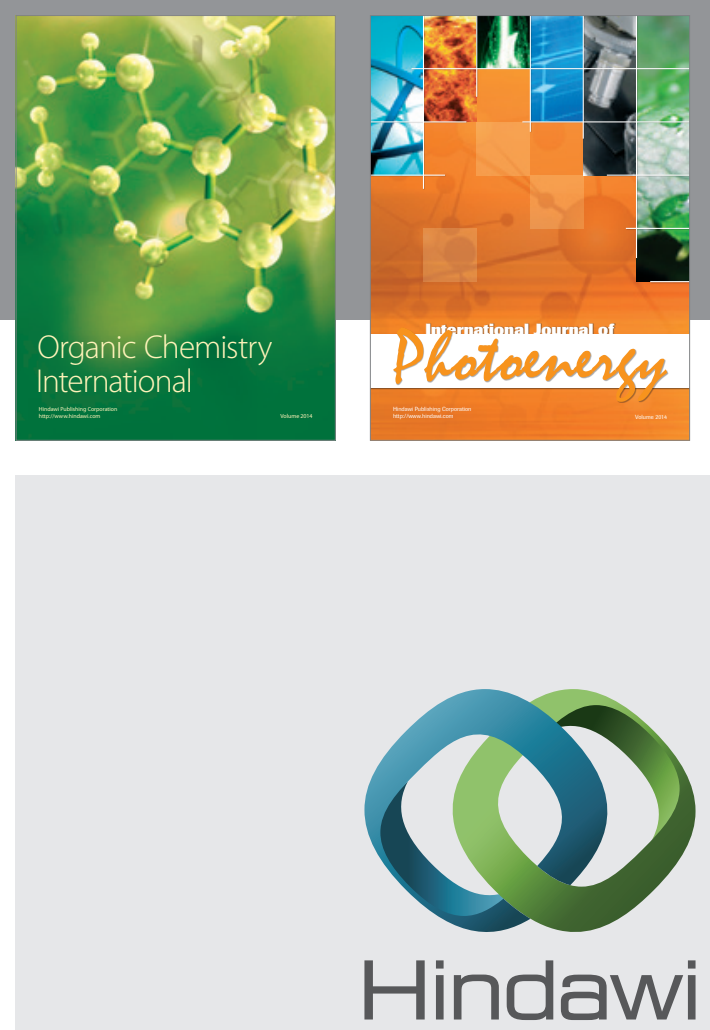

Submit your manuscripts at

http://www.hindawi.com
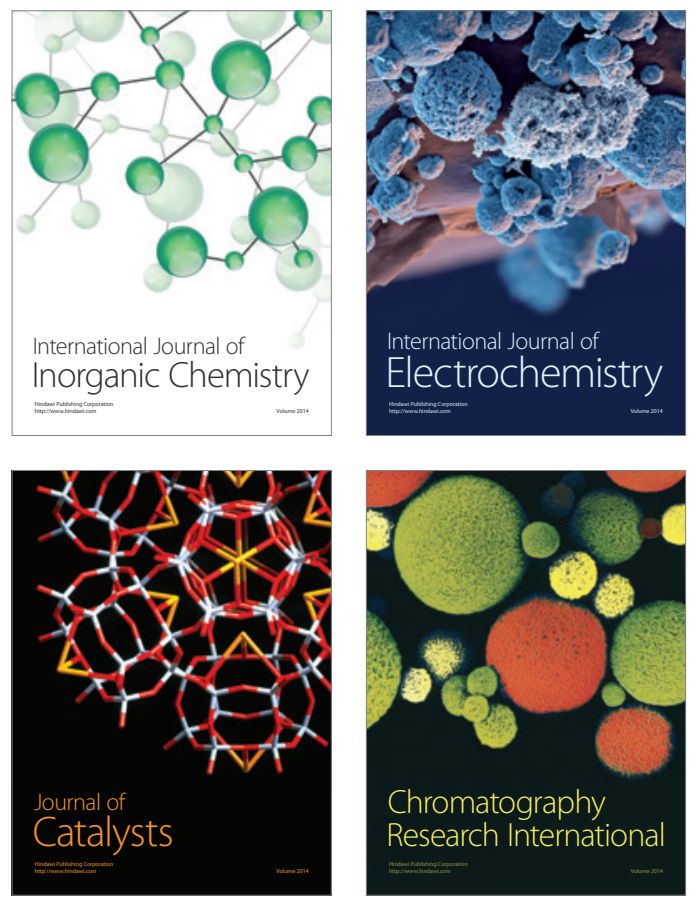
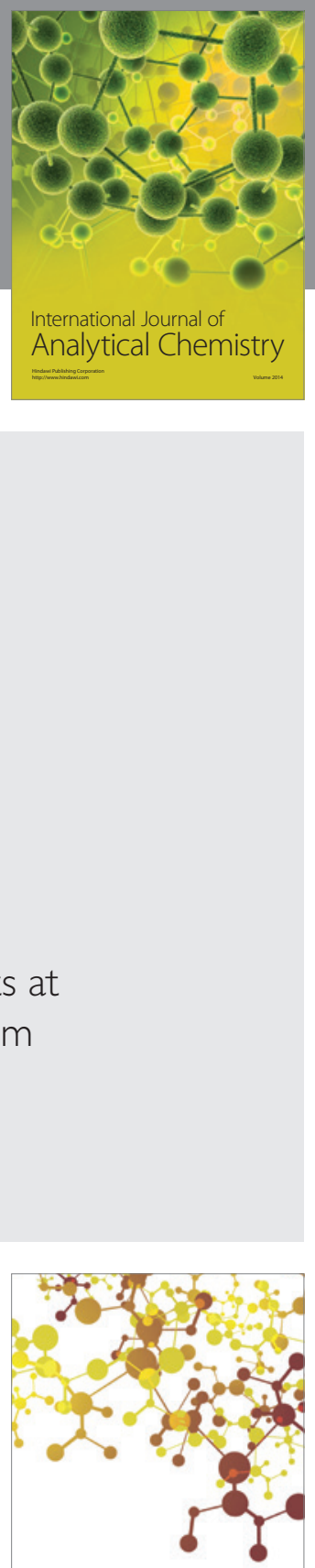

Journal of

Applied Chemistry
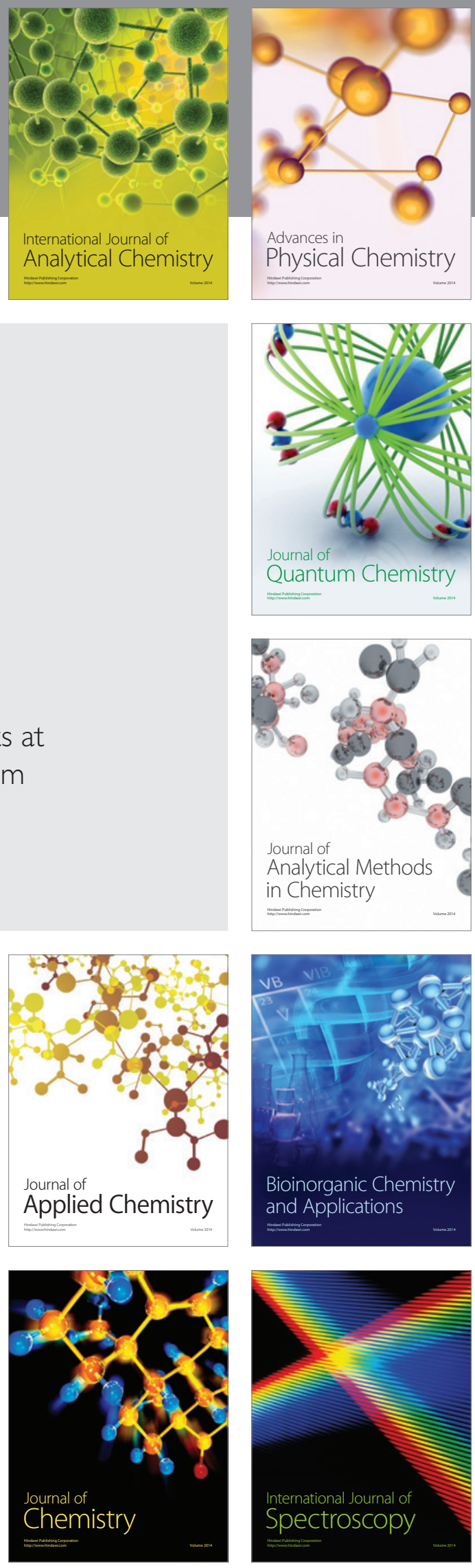